\title{
PENGARUH ALAT OVITRAP AIR RENDAMAN JERAMI PADI DAN OLESAN MINYAK PADA BOTOL PLASTIK TERHADAP NYAMUK TERPERANGKAP DI DESA RIMBO RECAP KECAMATAN CURUP SELATAN
}

\author{
Rustam Aji ${ }^{1}$ \\ 1.Prodi Keperawatan Curup Poltekkes Kemenkes Bengkulu \\ Alamat Email : adjieroestamadjie@gmail.com.
}

\begin{abstract}
ABSTRAK
Nyamuk jenis serangga dalam ordo diptera, dari kelas insecta. Nyamuk betina biasanya memilih jenis air tertentu untuk meletakkan telur seperti pada air bersih, air kotor,air payau,atau jenis air lainnya, disekitar lokasi penelitian merupakan daerah persawahan ,banyak jerami padi yang menumpuk. Jerami padi mengandung kadar ammonia, CO2, asam laktat dan octanol yang disukai nyamuk. Penelitian ini bertujuan mengetahui pengaruh alat ovitrap air rendaman jerami padi terhadap nyamuk terperangkap di Desa Rimbo Recap Curup Selatan.Jenis quasi eksperimental, analisis Chi-square, menghitung odds ratio, uji Chi kuadrat. Hampir seluruh $(94,4 \%)$ ada 34 nyamuk terendam didalam air jerami padi dan sebagian kecil $(5,5 \%)$ ada 2 nyamuk terperangkap dipermukaan botol plastik yang di olesi minyak, dari 36 nyamuk pada ovitrap rendaman jerami padi dalam $100 \mathrm{ml}$ air rendaman jerami padi dalam waktu 24 jam. Hasil analisis Chi-square nilaiP value $=0.04<\alpha 0.05$, ada pengaruh yang signifikan antara air rendaman jerami padi terhadap terperangkap nyamuk dalam rendaman air jerami padi.Dimana Nilai p value $=0.043$, mempunyai pengaruh air rendaman jerami padi, pada odds ratio $=4,10$ kali.Agar warga masyarakat berperan aktif mengurangi populasi nyamuk, melalui kegiatan membiasakan membuat rendaman jerami padi pada alat ovitrap, yang di letakkan di setiap sudut ruangan.
\end{abstract}

Kata Kunci : Jerami Padi, Nyamuk dan alat ovitrap.

\begin{abstract}
A type of insect in the order Diptera, from the insect class. Female mosquitoes usually choose certain types of water for laying eggs such as clean water, dirty water, brackish water, or other types of water, around the research location is a rice field area, a lot of rice straw has accumulated. Rice straw contains levels of ammonia, $\mathrm{CO} 2$, lactic acid and octanol which mosquitoes like. This study aims to determine the effect of rice straw soaking water ovitrap tool on trapped mosquitoes in the village of Rimbo Recap Curup Selatan. Quasi experimental type, Chi-square analysis, calculating odds ratios, Chi squared test. Almost all (94.4\%) there were 34 mosquitoes submerged in rice straw water and a small portion $(5.5 \%)$ there were 2 mosquitoes trapped on the surface of a plastic bottle smeared with oil, of the 36 mosquitoes on the ovitrap soaking rice straw in $100 \mathrm{ml}$ of soaking water rice straw within 24 hours. The results of the Chi-square analysis, the value of $\mathrm{P}$ value $=0.04<\alpha 0.05$, there is a significant effect between rice straw soaking water and mosquito trapping in rice straw water immersion. Where the $\mathrm{p}$ value $=0.043$, has the effect of rice straw soaking water, at odds ratio $=4.10$ times. In order for the community to play an active role in reducing the mosquito population, through the activity of getting used to making rice straw soaking in the ovitrap tool, which is placed in every corner of the room.
\end{abstract}

Keywords: Rice Straw, Mosquitoes and ovitrap tools. 
PENDAHULUAN.

Nyamuk jenis serangga dalam ordo diptera, dari kelas insecta. Populasi nyamuk banyak di sekitar rumah penduduk yang berdekatan di areal persawahan. Nyamuk betina menghisap darah bukan untuk mendapatkan makanan, melainkan untuk mendapatkan protein yang terdapat dalam darah, sebagai nutrisi untuk pematangan telurnya,nyamuk merupakan salah satu jenis serangga penghisap darah, banyak penyakit khususnya penyakit menular seperti demam berdarah, Japanese encephalitis, malaria filariasis ditularkan perantara nyamuk (Nugroho,2011)

Nyamuk jenis serangga dalam ordo diptera, dari kelas insecta.Nyamuk berina menghisap darah bukan untuk mendapatkan makanan, melainkan untuk mendapatkan protein yang terdapat dalam darah, sebagai nutrisi untuk pematangan telurnya,nyamuk membutuhkan air untuk hidupnya, karena larva nyamuk melanjutkan hidupnya di air dan hanya bentuk dewasa yang hidup di darat, telur nyamukmenetas dalam air dan menjadi larva.Nyamuk betina biasanya memilih jenis air tertentu untuk meletakkan telur seperti pada air bersih, air kotor,air payau,atau jenis air lainnya. Bahkan ada nyamuk yang meletakkan telurnya pada axil tanaman, lubang kayu (tree holes), tanaman berkantung yang dapat menampung air,atau dalam wadah bekas yang menampung air hujan atau air bersih (Rustam Aji Rochmat,2017).

Nyamuk merupakan salah satu jenis serangga penghisap darah, banyak penyakit khususnya penyakit menular seperti demam berdarah, Japanese encephalitis, malaria filariasis ditularkan perantara nyamuk. Rustam Aji, (2016).

Jerami padi mengandung kadar ammonia, CO2,asam laktat dan octanol. (Rahayu Anita, 2019).
Hairani Budi, (2020) Atraktan menunjukkan air rendaman jerami alangalang berpengaruh signifikan terhadap oviposisi nyamuk Aedes aegypti.menunjukkan ujiLSD konsentrasi atraktan $15 \%$ paling optimal dalam meningkatkan jumlah telur pada ovitrap.

Atraktan air rendaman jerami $10 \%$ dapat meningkatkan jumlah telur terperangkap delapan kali lipat terbukti menghasilkan $\mathrm{CO} 2$,ammonia dan etanol yang mempengaruhi saraf penciuman nyamuk (Sayono, 2007)

Peneliti memodifikasi alat ovitrap rendaman jerami padi, dirancang untuk membuat nyamuk betina tertarik dan mendatangi bahkan masuk ke dalam alat ovitrap, sehingga nyamuk akan terperangkap dalam alat ovitrap.

Modifikasi alat ovitrap dengan menggunakan $100 \mathrm{ml}$, air rendaman jerami padi,akan dapat memancing penciuman nyamuk betina untuk mendatangi alat ovitrap.

Survei yang dilakukan peneliti di sekitar areal persawahan pada lingkungan rumah warga Desa Rimbo Recap Kecamatan Curup Selatan. Peneliti mencari solusi untuk mengurangi populasi nyamuk di sekitar lingkungan rumah penduduk, dengan memanfaatkan jerami padi dan botol plastik bekas minuman air mineral, kemudian peneliti membuat modifikasi menjadi alat ovitrap perangkap nyamuk, natinya dapat di manfaatkan dan disosialisasikan di masyarakat.

Berdasarkan data tersebut diatas penulis meneliti tentang :" Pengaruh Alat Ovitrap Air Rendaman Jerami Padi Terhadap Nyamuk Terperangkap di Desa Rimbo Recap Kecamatan Curup Selatan”. 


\section{TUJUAN PENELITIAN}

Penelitian ini bertujuan untuk mengetahui : "Pengaruh Alat Ovitrap Air Rendaman Jerami Padi Terhadap Nyamuk Terperangkap di Desa Rimbo Recap Kecamatan Curup Selatan”.

\section{METODE}

Jenis penelitian ini bersifat quasi eksperimental yaitu penelitian yang mendekati percobaan sesungguhnya, untuk mengetahui : Pengaruh Alat Ovitrap Air Rendaman Jerami Padi Terhadap Nyamuk Terperangkap di Desa Rimbo Recap Kecamatan Curup Selatan.

Variabel dependen, yaitu jumlah dan persentase nyamuk yang terperangkap, dan jumlah dan persentase nyamuk yang menempel pada olesan minyak di permukaan botol plastik.

Variabel independennya yaitu pemberian rendaman air jerami padi, dianalisis dengan menggunakan tabulasi silang 2 x 2, menghitung odds ratio, dan uji Chi kuadrat. Sampel objek penelitian 36 nyamuk. Pelaksanaan penelitian 4 (empat) bulan.

Analisis yang digunakan adalah univariat untuk mengetahui : Pengaruh Alat Ovitrap Air Rendaman Jerami Padi Terhadap Nyamuk Terperangkap dan proporsi masing-masing setiap variabel yang diteili. Analisis bivariat untuk mengetahui pengaruh variabel independen dan dependen.

\section{ALAT DAN BAHAN PENELITIAN}

Peneliti menggunakan beberapa alat sebagai berikut : Pisau, gunting, botol plastik, minyak ,alat lem silicon,kuwas, jerami padi, air, spuit ukuran milimeter/gelas ukur, alat tulis dan kertas observasi,
Peneliti menggunakan beberapa bahan penelitian sebagai berikut antara lain potongan jerami padi, air dan nyamuk.

\section{CARA KERJA}

\section{Proses cara pembuatan rendaman air} jerami padi sebagai berikut :

1. Siapkan air 1 gelas belimbing atau sebanyak $100 \mathrm{ml}$.

2. Ambil 5 batang jerami padi selanjutnya dipotong-potong.

3. Potongan batang jerami padi, dimasukkan kedalam alat tabung rendaman masing-masing yang berisi $100 \mathrm{ml}$ air kemudian di proses sehingga menjadi air rendaman jerami padi.

4. Selanjutnya air rendaman jerami padi di beri lebel, kemudian masukkan rendaman jerami padi pada potongan botol plastik yang berisi air dengan ukuran $100 \mathrm{ml}$.

5. Potongan botol plastik dimodifikasi sedemian rupa, ada potongan botol plastik berisi tampungan air rendaman padi dan ada potongan botol plastik yang diberi olesan minyak pada pinggir botol plastik tersebut.

\section{Cara kerja alat ovitrap perangkap nyamuk, sebagai berikut :}

1. Siapkan alat ovitrap yang berisi air rendaman jerami padi dan modifikasi olesan minyak di permukaan botol plastik.

2. Kemudian modifikasi alat ovitrap di letakkan di lingkungan setiap sudut ruangan.

3. Biarkan dan amati selama 24 jam.bila lebih maka air rendaman jerami padi akan menimbulkan aroma yang kurang enak di ruangan.

4. Kemudian lihat dan hitung nyamuk yang terperangkap di alat ovitrap tersebut. 
5. Kemudian catat nyamukyang terperangakap padaalat ovitrap tersebut.

\section{Pelaksanaan prosedur penelitian sebagai berikut :}

1. Siapkan seluruh peralatan dan bahanbahan alat ovitrap yang diperlukan.

2. Ambil masing-masing alat ovitrap yang berisi air rendaman jerami padi yang berisi $100 \mathrm{ml}$ air rendaman jerami padi dan olesan permukaan botol plastik.

3. Kemudian modifikasi alat ovitrap di letakkan di lingkungan setiap sudut ruangan.

4. Biarkan dan amati selama 24 jam.bila lebih maka air rendaman jerami padi akan menimbulkan aroma yang kurang enak di ruangan.

5. Kemudian lihat dan hitung nyamuk yang terperangkap di alat ovitrap tersebut.

6. Kemudian catat nyamukyang terperangakap padaalat ovitrap tersebut.

7. Tabulasi data yang didapat kemudian dianalisa sesuai dengan metode statistik yang digunakan.
Data yang diperoleh dari hasil observasi terlebih dahulu dianalisa menggunakan desain cross sectional study, dianalisis dengan menggunakan tabulasi silang $2 \times 2$, mengetahui pengaruh alat ovitrap air rendaman jerami padi terhadap nyamuk dan menghitung odds ratio, dan uji Chi kuadrat. dengan tingkat kemaknaaan 0,05 . Tolak Ho jika p < (0,05). (Masturoh,2018)).

\section{Hasil Penelitian}

\section{Hasil Analisis Univariat}

Kegiatan dalam penelitian ini meliputi perhitungan jumlah nyamuk yang terperangkap dalam alat ovitrap rendaman air jerami padi dan olesan minyak pada permukaan botol plastik.yang direndam dalam air rendaman jerami padi selama 24 jam, pada masing-masing nyamuk yang terperangkap di dalam alat ovitrap berisi masing-masing $100 \mathrm{ml}$ air rendaman jerami padi dan olesan minyak pada permukaan botol plastik, maka didapatkan hasil seperti pada tabel berikut :

Tabel 1. Pengaruh Alat Ovitrap Air Rendaman Jerami Padi Terhadap Nyamuk Terperangkap.

\begin{tabular}{|l|c|c|c|c|c|c|}
\hline \multicolumn{8}{|c|}{ Pengaruh Alat Ovitrap Air Rendaman Jerami Padi Terhadap Nyamuk Terperangkap } \\
\hline \multirow{3}{*}{ Pengaruh Alat Ovitrap } & \multicolumn{6}{|c|}{ Nyamuk Terperangkap pada alat ovitrap } \\
\cline { 2 - 8 } & \multicolumn{2}{|c|}{ Rendaman Jerami Padi } & Olesan minyak pada botol plastik & \multicolumn{3}{c|}{ Total } \\
\cline { 2 - 8 } & $\mathrm{n}$ & $\%$ & $\mathrm{n}$ & $\%$ & $\mathrm{n}$ & $\%$ \\
\hline Ya & 34 & 94,4 & 2 & 5,5 & 36 & 100 \\
\hline Tidak & 0 & 0 & 36 & 100 & 36 & 100 \\
\hline
\end{tabular}

Berdasarkan Tabel.1 diatas, menunjukkan bahwa : Hampir seluruh $(94,4 \%)$ ada 34 nyamuk terendam didalam air jerami padi pada alat ovitrap. 
Tabel 2. Pengaruh Alat Ovitrap Olesan minyak pada botol plastik Terhadap Nyamuk Terperangkap.

\begin{tabular}{lccccccc}
\hline \multicolumn{3}{c}{ Pengaruh Alat Ovitrap Rendaman Jerami Padi dan Olesan minyak pada botol plastik } \\
Terhadap Nyamuk Terperangkap. \\
$\begin{array}{l}\text { Pengaruh } \\
\text { Ovitrap }\end{array}$
\end{tabular}

Berdasarkan Tabel.2 diatas, menunjukkan bahwa : Sebagian kecil $(5,5 \%)$ ada 2 nyamuk terperangkap dipermukaan botol plastik yang di olesi minyak, dalam waktu 24 jam.

\section{Hasil Analisis Bivariat}

Kegiatan dalam penelitian ini meliputi perhitungan jumlah nyamuk yang terperangkap dengan pengaruh air rendaman jerami padi dan olesan minyak botol pelastik, Proses pengamatan pada 36 nyamuk yang terperangkap yang direndam dalam air rendaman jerami padi dan olesan minyak botol pelastik selama maksimal 24 jam, pada masing-masing nyamuk yang terperangkap, yang berada di dalam alat ovitrap berisi masing-masing $100 \mathrm{ml}$ air rendaman jerami padi dan olesan minyak botol pelastik, maka didapatkan hasil seperti pada tabel berikut :

\section{Tabel 3 Pengaruh Alat Ovitrap Rendaman Jerami Padi dan Olesan minyak pada botol plastik Terhadap Nyamuk Terperangkap..}

\begin{tabular}{|c|c|c|c|c|c|c|}
\hline \multicolumn{7}{|c|}{ Pengaruh Alat Ovitrap Air Rendaman Jerami Padi Terhadap Nyamuk Terperangkap } \\
\hline \multirow{3}{*}{ Pengaruh Alat Ovitrap } & \multicolumn{6}{|c|}{ Nyamuk Terperangkap pada alat ovitrap } \\
\hline & \multicolumn{2}{|c|}{ Rendaman Jerami Padi } & \multicolumn{2}{|c|}{ Olesan minyak pada botol plastik } & \multicolumn{2}{|c|}{ Total } \\
\hline & $\mathrm{n}$ & $\%$ & $\mathrm{n}$ & $\%$ & $\mathrm{n}$ & $\%$ \\
\hline $\mathrm{Ya}$ & 34 & 94,4 & 2 & 5,5 & 36 & 100 \\
\hline Tidak & 0 & 0 & 36 & 100 & 36 & 100 \\
\hline
\end{tabular}

Hasil analisis bivariat berdasarkan tabel 3 diatas,menunjukkan bahwa Chi-square nilaiP value $=0.04<\alpha 0.05$, ada pengaruh yang signifikan antara air rendaman jerami padi terhadap terperangkap nyamuk dalam rendaman air jerami padi. Dimana Nilai $\mathrm{p}$ value $=0.043$, mempunyai pengaruh air rendaman jerami padi, pada odds ratio $=$ 4,10 kali.

\section{Pembahasan Penelitian}

\subsection{Pembahasan penelitian}

Berdasarkan hasil pengamatan yang dilakukan hasil uji coba air rendaman jerami padi dan olesan minyak padapermukaan botol pelastik dengan 
formulasi yang sama, menyebabkan jumlah nyamuk yang terperangakap pada alat ovitrap yang berbeda dengan rentang waktu yang sama, hasil yang diperoleh sebagai berikut :

\subsubsection{Pengaruh nyamuk yang terperangkap dalam rendaman jerami padi dan olesan minyak pada alat ovitrap.}

Hasil penelitian ini ada pengaruh yang signifikan alat ovitrap air rendaman jerami padi terhadap nyamuk yang terperangkap

Sependapat dari hasil penelitian dari Rahayu Anita, (2019), bahwa jerami padi mengandung kadar ammonia, $\mathrm{CO} 2$, asam laktat dan octanol.

Sejalan dari hasil penelitian dari Hairani Budi, (2020) Atraktan menunjukkan air rendaman jerami alangalang berpengaruh signifikan terhadap oviposisi nyamuk Aedes aegypti.menunjukkan uji LSD konsentrasi atraktan $15 \%$ paling optimal dalam meningkatkan jumlah telur pada ovitrap.

Sependapat dari Sayono (2007) Atraktan air rendaman jerami $10 \%$ dapat meningkatkan jumlah telur terperangkap delapan kali lipat terbukti menghasilkan CO2,ammonia dan etanol yang mempengaruhi saraf penciuman nyamuk

Simpulan peneliti bahwa rendaman jerami padi dan olesan minyak padapermukaan botol pelastik, hampir seluruh $(94,4 \%)$ ada 34 nyamuk terendam didalam air jerami padi dan sebagian kecil $(5,5 \%)$ ada 2 nyamuk terperangkap dipermukaan botol plastik yang di olesi minyak, dari 36 nyamuk pada ovitrap rendaman jerami padi dalam $100 \mathrm{ml}$ air rendaman jerami padi dalam waktu 24 jam.

Berdasarkan analisis Chi-square nilaiP value $=0.04<\alpha 0.05$, ada pengaruh yang signifikan antara air rendaman jerami padi terhadap terperangkap nyamuk dalam rendaman air jerami padi.Dimana Nilai $\mathrm{p}$ value $=0.043$, mempunyai pengaruh air rendaman jerami padi, pada odds ratio $=$ 4,10 kali.

\section{PENUTUP}

\section{Kesimpulan}

1. Jerami padi mengandung kadar ammonia, CO2,asam laktat dan octanol, dapat memancing penciuman nyamuk, sehingga nyamuk tertarik dan mendekat masuk ke alat ovitrap rendaman jerami padi..

2. Hasil analisis univariat menunjukkan bahwa hampir seluruh dari 34 nyamuk terendam didalam air jerami padi dan sebagian kecil ada 2 nyamuk terperangkap dipermukaan botol plastik yang di olesi minyak, dari 36 nyamuk pada ovitrap rendaman jerami padi dalam $100 \mathrm{ml}$ air rendaman jerami padi dalam waktu 24 jam.

3. Hasil analisis bivariat, menunjukkan bahwa, mempunyai pengaruh air rendaman jerami padi, pada odds ratio $=4,10$ kali.

\section{Saran}

Warga masyarakat di harapkan agar warga masyarakat berperan aktif mengurangi populasi nyamuk, melalui kegiatan membiasakan membuat rendaman jerami padi pada alat ovitrap, yang di letakkan di setiap sudut ruangan.

\section{DAFTAR PUSTAKA}

Aji Rustam Rochmat, (2017)
Serai Wangi terhadap
Keberadaan larva Jentik Aeges
aegypti pada Tempat
Penampungan Air.JVK.3 (1)
(2017) hlm.1-4. http://ejournal
poltekkes-
pontianak.ac.id/index.php/JVK


Aji Rustam ,dkk (2016) Environmental Factors and Indices Related to Dengue Vector Larva in Rejang Lebong District. IRJEPEH.Vol.3(7),pp.162166-July-2016.ISSN.23608803.http.//dx.doi.org/10.1573 9/irjpeh.16.021.

Hairani Budi,dkk (2020) Efektivitas Air Rendaman Jerami Alang-alang (Imperata cylindrica) sebagai Aktarktan terhadap Jumlah Telur Aedes Aegypti.Balai penelitian dan Pengembangan Kesehatan Tanah Bumbu.BALABA

Vol.16.No.1,Juni 2020:39-46.

Masturoh Imas, Anggita Nauri, (2018) Metodologi Penelitian Kesehatan.Pusat Pendidikan Sumber Daya Manusia Kesehatan Badan Pengembangan dan Pemberdayaan Sumber Daya Manusia Kesehatan.Edisi Tahun 2018.Kementerian Kesehatan Republik Indonesia.

Nugroho Arif Dwi, (2011) Kematian larva Aedes aegypti setelah Pemberian Abate di bandingkan dengan pemberian serbuk serai.KESMAS..7 (1) (2011) 9196.http://Journal.unnes.ac.id/in dex.php/kemas.

Rahayu Anita, dkk (2019) Pengaruh Berbagai Konsentrasi Air Rendaman Jerami Terhadap Jumlah Telur Nyamuk di Desa Sukajaya Punduh Kecamatan Marga Punduh Kabupaten Pesawaran Provinsi Lampung. Fakultas Kedokteran Universitas

Lampung.Medula,Volume.9, ha 1.148.Nomor.1,Juli-2019,
Sayono, dkk (2007 Pengaruh Modifikasi Ovitrap Terhadap Jumlah Nyamuk Aede Yang Terperangkap. FK.Kesehatan Masyarakat. Universitas Muhammadyah Semarang. Program Magister Epidemiologi Universitas Di Ponegoro Semarang. 
